\title{
SURGING OF FISHER GLACIER, EASTERN ANTARCTICA : EVIDENCE FROM GEOMORPHOLOGY
}

\author{
By Peter Wellman
}

(Bureau of Mineral Resources, Geology and Geophysics, Canberra, A.C.T. 2601, Australia)

\begin{abstract}
A study of the geomorphology of the Prince Charles Mountains using colour vertical air photographs shows well-preserved old moraines throughout much of the outcrop area. Along Fisher Glacier, lower Lambert Glacier and the Amery Ice Shelf, within the altitude range 50-2000 m, the old moraines show that the ice level had risen 150-200 m above the present level at least three times. Old moraines elsewhere show that none of the other glaciers had risen significantly in their upper parts; the rise of their lower parts was caused by the rise of lower Lambert Glacier and the Amery Ice Shelf. The changes in ice level are unlikely to be due to climatic change because this would not repeatedly affect only one glacier draining central Antarctica. It is thought that the changes in ice level are caused by repeated surges of Fisher Glacier.
\end{abstract}

RÉSUMÉ. Crue du Fisher Glacier, Est Antarctique; preuves géomorphologiques. Une ètude des Prince Charles Mountains par photographies aériennes verticales en couleur montre une vieille moraine bien conservée à travers la plus grande part de la zone externe du massif. Le long du Fisher Glacier, dans le bas du Lambert Glacier et de l'Amery Ice Shelf, dans la gamme d'altitude de 50 à $2000 \mathrm{~m}$ les vieilles moraines prouvent que la glace s'est élevée de 150 à $200 \mathrm{~m}$ au-dessus de son niveau actuel à trois reprises au moins. Ailleurs les vieilles moraines montrent qu'aucun des autres glaciers n'ont eu de crues significatives dans leurs parties hautes; le gonflement de leur partie inférieure a été causé par celui de la partie inférieure du Lambert Glacier et de l'Amery Ice Shelf. Les variations dans le niveau de la glace ne sont pas probablement dues à des variations climatiques parce qu'elles n'auraient pas affecté répétitivement seulement un seul des glaciers drainant l'Antarctique central. On pense que ces variations de niveau de glace sont entraînées par des crues répétées du Fisher Glacier.

ZuSAMmENFASSUNG. Ausbrüche des Fisher Glacier, Ost-Antarktis; geomorphologische Anzeichen. Eine geomorphologische Untersuchung der Prince Charles Mountains anhand von farbigen Senkrechtaufnahmen zeigt wohlerhaltene alte Moränen in einem Grossteil des Vorlandes. Längs des Fisher Glacier, des unteren Lambert Glacier und des Amery Ice Shelf, im Höhenbereich von 50-2000 m, zeigen die alten Moränen, dass die Eishöhe mindestens dreimal 150-200 m über das heutige Niveau angestiegen war. Sonstige alte Moränen schliessen ein signifikantes Ansteigen der anderen Gletscher in ihren oberen Teilen aus; der Anstieg ihrer unteren Teile ist auf den Anstieg des unteren Lambert Glacier und des Amery Ice Shelf zurückzuführen. Die Veränderungen der Eishöhe beruhen vermutlich nicht auf Klimaschwankungen, weil solche nicht nur einen der Abflussgletscher der Innerantarktis wiederholt beeinflusst hätten. Es ist vielmehr anzunehmen, dass die Eishöhenschwankungen durch wiederholte Ausbrüche des Fisher Glacier verursacht sind.

\section{INTRODUCTION}

One of the major problems in understanding the dynamics of the Antarctic ice sheet is to determine whether the flow is steady or fluctuates with a period of thousands of years. Over much of Antarctica the net ice-accumulation rate is greater than the flow rate to the sea (Allison, 1979), suggesting that the ice thickness is slowly increasing at present, and that the flow is not steady but may surge periodically.

In this context the Lambert Glacier and Amery Ice Shelf drainage system is important; it drains the central part of the east Antarctic ice sheet, and it is the fourth largest drainage system in Antarctica (Fig. 1).

Suggestions that Lambert Glacier could surge periodically come from two sources: from consideration of the flux rate and surface slope of Lambert Glacier (Budd and McInnes, $\left[{ }^{\mathrm{C}} 1978\right]$ ), and from consideration of detailed glaciological measurements, which show that the present flow out of the Lambert Glacier basin is about one-half the average accumulation rate within the basin (Allison, 1979). As yet, however, there is no published geomorphological evidence for surging of any Antarctic glaciers.

The ice surface of lower Lambert Glacier and the Amery Ice Shelf ranges from 50 to $300 \mathrm{~m}$ above sea-level, and is about $2000 \mathrm{~m}$ below the surface of the surrounding ice sheet. In this relative depression, numerous bedrock nunataks are exposed from the coastline to $500 \mathrm{~km}$ inland; these nunataks form the Prince Charles Mountains. I have recently made a study of the 


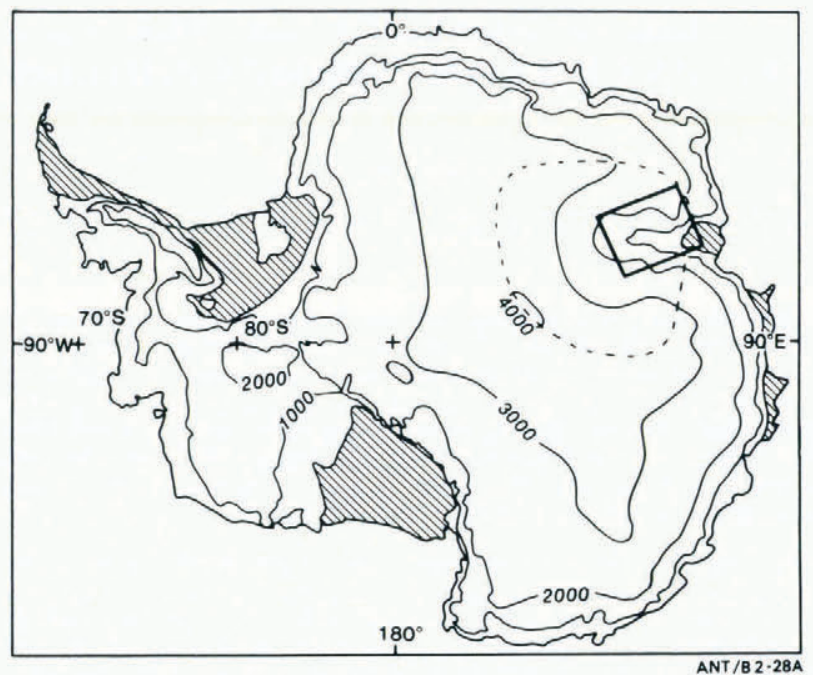

Fig. 1. Antarctica, showing ice-surface contours (solid lines), and the exent of the catchment of lower Lambert Glacier (dashed line). The box shows the location of Figure 2.

nunataks using colour vertical air photographs at 1:60000 scale, flown between 1971 and 1974 by the Commonwealth of Australia's Division of National Mapping.

\section{GEOMORPHOLOGY}

The regional geomorphology of the Prince Charles Mountains area was described by Trail (1964), the landforms of a more important nunatak, Mount Menzies, by Derbyshire and Peterson (1978), and the weathering and mineralogy of the moraines by Bardin (in press). Bedrock geology was described by Tingey (in press).

Trail (1964) recognized marginal moraines $50 \mathrm{~m}$ above the present ice level and he attributed them to fluctuations of the present ice-drainage system. Tingey and England (unpublished) and Tingey (1974), from the presence of vertical cliffs and the retention of a soft clay fraction in a high moraine, inferred that at Mount Stinear the Lambert Glacier surface has recently dropped $800 \mathrm{~m}$.

The relief of rock above the general ice level ranges from about $1000 \mathrm{~m}$ along the axis of lower Lambert Glacier to zero at about $2000 \mathrm{~m}$ altitude on the plateau. Rock above the general ice level is usually less well exposed at higher altitudes, because it is increasingly draped by ice and snow.

The relative ages of rock surfaces, screes, and moraines have been primarily determined by the principle of superposition at places where an upper formation covers part of a lower formation. These relative ages have been roughly correlated throughout the area by assuming the same age for similar rocks with the same amount of weathering and ice wedging.

The relative age of the surface of exposed, glaciated solid rock can be roughly determined by the amount of non-glacial modification-by the extent of covering screes where the surface is steep, and by the depth of differential wind erosion in flat exposed areas.

The relative ages of the surface of surficial deposits such as moraine and scree can be determined by surface appearance and colour. On air photographs, young moraines generally have the texture of fine sandpaper-this is due to large boulders that project above the general surface. On a larger scale, either the surface is smooth, except for rare sinuous depositional 
ridges, or it consists of a thermokarst topography (of large closed depressions) which has quickly replaced the smooth initial surface, by the melting of underlying dead ice (Derbyshire and Peterson, 1978). On old moraines these surface features are partly or completely destroyed by the action of ice wedges; these initially flatten the surface and later form patterned ground-a polygonal pattern of raised mounds up to $10 \mathrm{~m}$ in diameter and $3 \mathrm{~m}$ in height (Trail, 1964). Commonly, the moraine is black when fresh, and becomes grey and then red as weathering increases with time. The same colour changes and development of patterned ground also take place on scree and so can be used to estimate relative ages of the upper surface of screes.

In areas where moraine is at present being deposited there are commonly remnants of higher and older parallel moraines, which are thought to have been deposited by higher ice with about the same flow pattern as today. The upper moraine limit is usually well defined; it often consists of a line of exceptionally large boulders or a low symmetrical ridge several metres high. Between the upper limit and the present ice level, the moraine in cross-section appears to be nearly uniform in thickness. At places where the moraine is thin it can usually be seen to rest on unmodified older, strongly patterned ground (Wilson, 1978). At the down-stream end of nunataks, thin moraine often rests on glaciated bedrock with a surface of the same age as the moraine. Generally the moraine is too thick to see through.

\section{HeIGHT OF OLD MORAINES}

The term "moraine height" is used here for the height of the top of the old moraine above the top of the present-day marginal moraine.

The relation between ice-surface altitude and moraine height is shown in plan in Figure 2 and in cross-section in Figure 3. Moraine heights were obtained from air photographs by parallaxbar measurements; they have an uncertainty of $10 \%$. Ice-surface altitudes south of lat. $72^{\circ} \mathrm{S}$. are from Morgan and Budd (1975), in the northern outcrop area from unpublished barometric traverses using helicopter transport, and elsewhere from published 1:1000 000 maps.

Most of the old moraines are thought to be of the same age, because their surface has the same geomorphic age and because most of the moraine heights conform to a regular pattern. The other old moraines are considerably older.

In the northern Prince Charles Mountains along the east-flowing Scylla and Charybdis Glaciers (cross-sections $\mathrm{A}-\mathrm{A}^{\prime}$ and $\mathrm{B}-\mathrm{B}^{\prime}$ of Figure 3 ), the moraine heights generally increase systematically down-stream, from zero at $1500 \mathrm{~m}$ glacier altitude to an observed maximum of about $100 \mathrm{~m}$ at $500 \mathrm{~m}$ glacier altitude. Hence moraine height changes by about $-0.1 \mathrm{~m}$ for every metre change in glacier altitude. West of Mount Meredith and near Shaw Massif (cross-sections $\mathrm{C}-\mathrm{C}^{\prime}$ and $\mathrm{D}-\mathrm{D}^{\prime}$ ), some old moraine heights have a similar trend but some are anomalously low. For Fisher Glacier (cross-section $\mathrm{E}-\mathrm{E}^{\prime}$ ), the moraine height is constant at approximately $200 \mathrm{~m}$, from $2000 \mathrm{~m}$ to $600 \mathrm{~m}$ glacier altitude. At nunataks adjacent to lower Lambert Glacier (cross-section $\mathrm{F}-\mathrm{F}^{\prime}$ ), moraine heights are roughly constant at about $200 \mathrm{~m}$, the altitude of the adjacent glacier ice ranging from 600 to $50 \mathrm{~m}$.

The centre of lower Lambert Glacier and the Amery Ice Shelf are slightly lower than the edge adjacent to the nunataks (Fig. 2). In order to estimate the former ice level of the centre of lower Lambert Glacier and the Amery Ice Shelf, the moraine-height data are extrapolated using the $-0.1 \mathrm{~m}$ per $\mathrm{m}$ relation derived above. These estimates are shown as asterisks in the Figure 3 cross-sections. They give an ice level of $200 \pm 20 \mathrm{~m}$ above present level for the centre of lower Lambert Glacier from lat. $73^{\circ}$ to $71^{\circ} \mathrm{S}$., and about $150 \mathrm{~m}$ for the centre of the Amery Ice Shelf at lat. $70^{\circ} \mathrm{S}$.

No old moraine was recognized on the nunataks between Mellor Glacier and upper Lambert Glacier, although suitable sites exist for presentation of old moraines, and new moraines are widespread. Along Mawson Escarpment old moraines are weakly developed. 


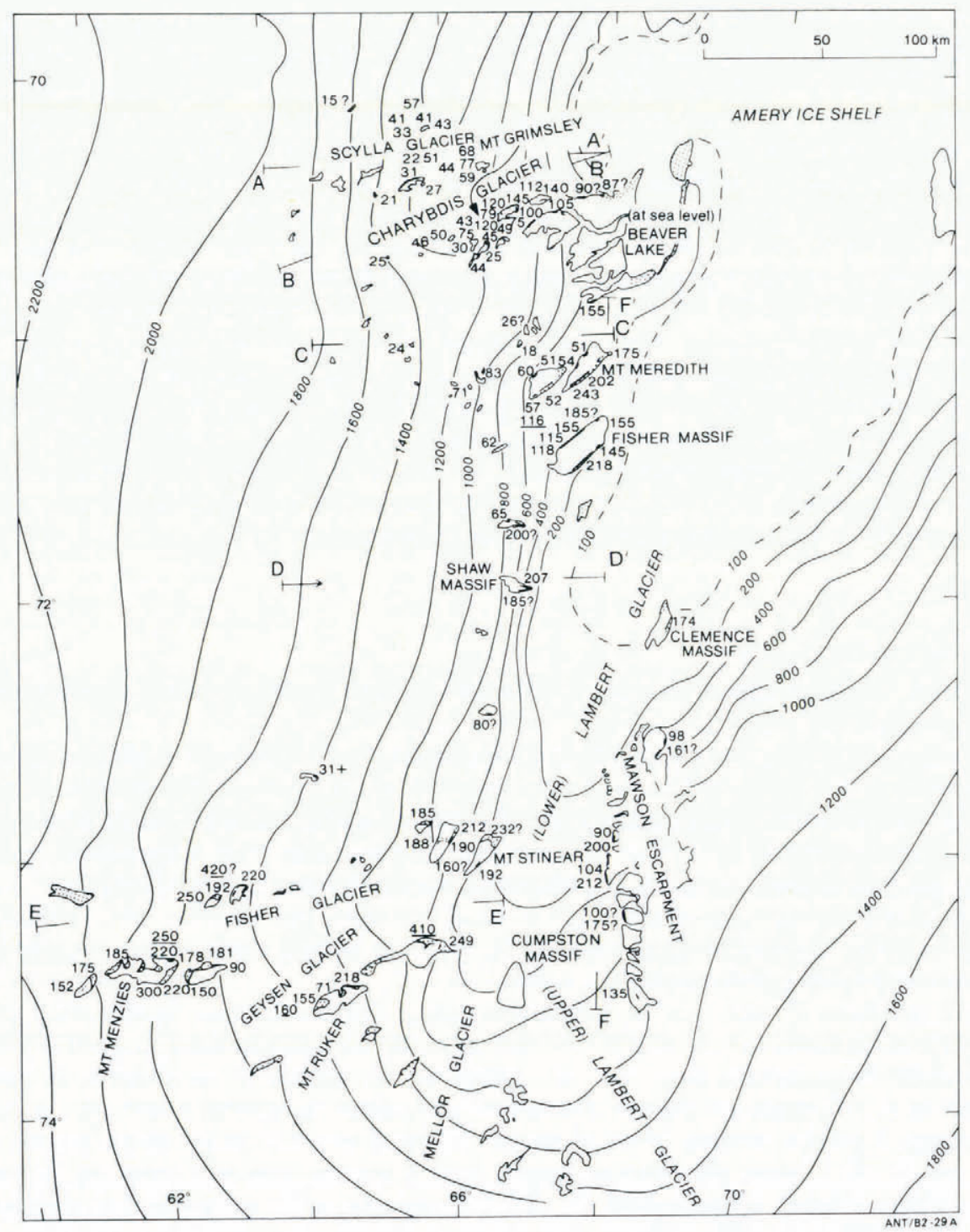

Fig. 2. Prince Charles Mountains. Contours give the ice-surface altitude in metres. Stippled areas are present-day and old moraines. Thick lines and numbers give the extent of old moraines and the "moraine height" in metres. If the number is underlined the moraine is exceptionally old. The positions of Figure 3 cross-sections are shown.

In the Fisher Glacier area, old moraines of three distinct ages are recognized at Mount Menzies and Mount Ruker (lat. $73^{\circ} 37^{\prime}$ S., long. $64^{\circ} 20^{\prime}$ E.), and of two distinct ages at Mount Rubin (lat. $73^{\circ} 30^{\prime}$ S., long. $65^{\circ} 40^{\prime}$ E.), and possibly at Mount Scherger (lat. $73^{\circ} 15^{\prime}$ S., long. $62^{\circ} 50^{\prime}$ E.). The older moraines are $20-50 \%$ higher and of much larger volume than the latest moraine. At Mount Menzies and Mount Ruker, the three moraines are well separated in time, the youngest having minor surface weathering and slight or no development of patterned ground, and the oldest being strongly weathered and having depositional features and patterned ground equally prominent. A rise in glacier level and deposition of a moraine would largely destroy 


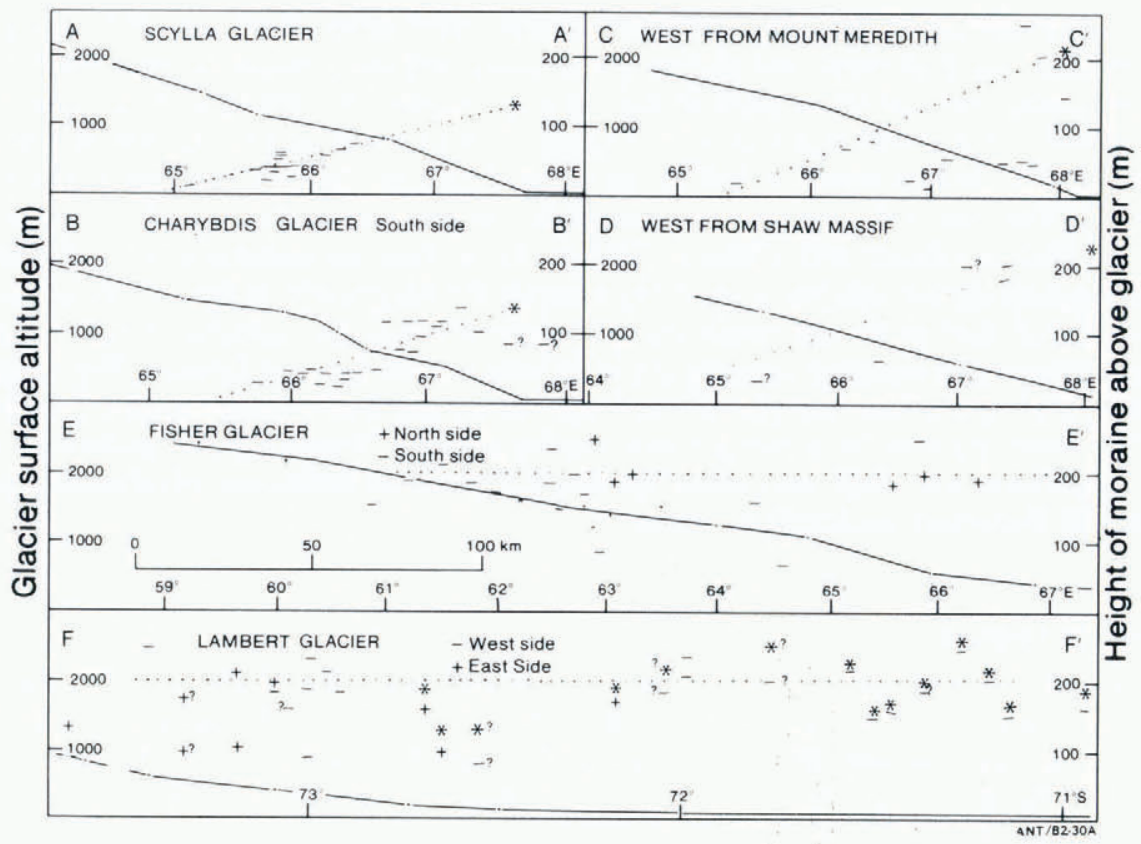

Fig. 3. Sections along glaciers. Their locations are given in Figure 2. The variation in altitude of the glacier surface is given by solid lines between observed values. Moraine-height measurements above glacier surface are given by dashes and crosses; the dotted line gives the mean height relation ignoring the exceptionally small moraine heights west of Mount Meredith and Fisher Massif on cross-section $C-C^{\prime}$. Stars show the calculated theoretical moraine height, i.e. the former maximum ice-surface altitude, at the centre of the Amery Ice Shelf and lower Lambert Glacier.

evidence for earlier smaller rises, so it seems likely that there have been unrecorded slightly smaller rises, and the total number of rises is greater than three. In the northern Prince Charles Mountains, moraines of two distinct ages are poorly developed at Mount Lanyon (lat. $71^{\circ} 15^{\prime} \mathrm{S}$., long. $67^{\circ} 10^{\prime}$ E.) and Mount Trott (lat. $70^{\circ} 45^{\prime}$ S., long. $66^{\circ} 20^{\prime}$ E.).

Moraines along the margin of Fisher Glacier and lower Lambert Glacier differ from moraines along Scylla Glacier and Charybdis Glacier. Fisher Glacier and lower Lambert Glacier moraines thinly cover the lower part of patterned and unpatterned screes, thinly cover older patterned ground, form thick deposits on some areas of flat ground, and at the down-stream end of some large nunataks they often rest on irregularly sculptured unweathered bedrock. This bedrock contains rare closed depressions with a base $100 \mathrm{~m}$ below the level of adjacent solid rock and nearby glacier; these depressions contain only minor moraine. Along Scylla Glacier and Charybdis Glacier, the youngest of the old moraines thinly covers unpatterned scree, but on patterned ground the moraine often appears to be a thick composite of several moraines with a similar height; the outer moraine is thin and relatively unweathered, and the inner moraine(s) is thick and strongly patterned.

\section{Climatic Changes or Surges}

The glaciers draining into Lambert Glacier have catchments remote from the ocean, so any temporary increase in accumulation rate is likely to affect the catchment of several glaciers of the drainage system and result in simultaneous higher ice-sheet and glacier levels in these adjacent catchments. It is unlikely that there will be repeated increases in accumulation rate in one 
catchment area which do not affect adjacent similar catchments. However, if the accumulation rate is constant, then ice-sheet and glacier levels would remain constant in most catchments but would repeatedly rise and fall in periodically surging catchments. There is good evidence for no change in ice level at $2000 \mathrm{~m}$ in the area of upper Scylla Glacier and Charybdis Glacier, poorer evidence for no change above $1200 \mathrm{~m}$ on upper Lambert Glacier, and at $1000 \mathrm{~m}$ east of Mawson Escarpment, and very strong evidence for at least three changes of $200 \mathrm{~m}$ at $2000 \mathrm{~m}$ altitude on Fisher Glacier and Geysen Glacier. This observed pattern is not consistent with changes in accumulation rate but is perfectly consistent with periodic surges of one catchment.

It is inferred that all the old moraines are caused by repeated surging of Fisher Glacier, or possibly simultaneous repeated surging of Fisher Glacier and Geysen Glacier. The surges would raise the level of lower Lambert Glacier and the Amery Ice Shelf, which in turn would raise the level of the lower part of the other glaciers. During a surge, Fisher Glacier and lower Lambert Glacier would have very high velocities; this would explain the difference between their moraines and moraines elsewhere, as described above.

\section{ACKNOWLEDGEMENTS}

For the air-photograph coverage I wish to thank surveyors of the Division of National Mapping and support members of the Australian National Antarctic Research Expeditions. I am grateful for discussions with R. J. Tingey, D. S. Trail, Professor H. W. Wellman, and I. F. Allison. The figures were drawn by J. Rayner-Sharpe. Publication is by permission of the Director, Bureau of Mineral Resources, Canberra.

MS. received 24 June 1980 and in revised form 15 November 1980

\section{REFERENCES}

Allison, I. F. 1979. The mass budget of the Lambert Glacier drainage basin, Antarctica. Journal of Glaciology, Vol. 22, No. 87, p. 223-35.

Bardin, V. I. In press. Lithology of East Antarctic moraine and some problems of Cainozoic history. (In Craddock, C., ed. Antarctic geoscience. Proceedings of the third Symposium on Antarctic Geology and Geophysics, Madison, 22-27 August 1977. Madison, University of Wisconsin Press.)

Budd, W. F., and McInnes, B. [ ${ }^{\mathrm{C}} 1978$.] Modelling surging glaciers and periodic surging of the Antarctic ice sheet. (In Pittock, A. B., and others, ed. Climatic change and variability: a southern perspective..... Editors: A. B. Pittock, L. A. Frakes, D. Jenssen, J. A. Peterson, J. W. Zillman on behalf of the A ustralian Branch, Royal Meteorological Society. Cambridge, etc., Cambridge University Press, p. 228-33.)

Derbyshire, E., and Peterson, J. A. 1978. A photo-geomorphic map of the Mt. Menzies nunatak, Prince Charles Mountains, Australian Antarctic Territory. Zeitschrift für Gletscherkunde und Glazialgeologie, Bd. 14, Ht. I, p. $17-26$.

Morgan, V. I., and Budd, W. F. 1975. Radio-echo sounding of the Lambert Glacier basin. Journal of Glaciology, Vol. 15 , No. 73 , p. 103-11.

Tingey, R. J. 1974. Australian geological mapping in the Prince Charles Mountains, 1968-73. Polar Record, Vol. 17. No. 107 , p. $150-53$.

Tingey, R. J. In press. The geology and geological evolution of the Prince Charles Mountains, Antarctica. (In Craddock, C., ed. Antarctic geoscience. Proceedings of the third Symposium on Antarctic Geology and Geophysics, Madison, 22-27 August 1977. Madison, University of Wisconsin Press.)

Tingey, R. J., and England, R. N. Unpublished. Geological work in Antarctica-1972. [Bureau of Mineral Resources, Australia, Record 1973/161.]

Trail, D. S. 1964. The glacial geology of the Prince Charles Mountains. (In Adie, R. J., ed. Antarctic geology. Proceedings of the first international symposium on Antarctic geology, Cape Town, 16-2I September 196.3. Amsterdam, North-Holland Publishing Co., p. 143-51.)

Wilson, A. T. 1978. Glacial history of New Zealand and the Ross Dependency, Antarctica. (In Zinderen Bakker. E. M. van, sr, ed. Antarctic glacial history and world palaeoenvironments. International Council of Scientific Unions. Scientific Committee on Antarctic Research. Proceedings of a symposium held on 17th August, 1977 during the Xth INQUA Congress at Birmingham, U.K. Rotterdam, A. A. Balkema, p. 15-23.) 